\title{
The concept of "Loop Cycle" in landfill management (Case study at Piyungan landfill, Yogyakarta, Indonesia)
}

\author{
Hijrah Purnama Putra $^{1, *}$, Enri Damanhuri ${ }^{2}$, and Akhmad Marzuko ${ }^{3}$ \\ ${ }^{1}$ Department of Environmental Engineering, FTSP Universitas Islam Indonesia, \\ Jalan Kaliurang km 14,5 Sleman, Yogyakarta 55584, Indonesia \\ ${ }^{2}$ Department of Environmental Engineering, FTSL Institut Teknologi Bandung \\ Jalan Ganesa 10, Bandung 40132, Indonesia \\ ${ }^{3}$ Department of Civil Engineering, FTSP Universitas Islam Indonesia, \\ Jalan Kaliurang km 14,5 Sleman, Yogyakarta 55584, Indonesia
}

\begin{abstract}
The amount of waste continues to increase from year to year, one of which is due to the population increase. With the target of $100 \%$ service level by 2020 , Indonesia must prepare the land that will be used as a landfill location in order to accommodate the waste that continues to be produced. Apparently, the problem is not only limited to the provision of land, but operational challenges become more severe. One of its is experienced by Piyungan Landfill, Bantul, Yogyakarta which has been designed to expire by 2015 . The government of Yogyakarta is optimizing for landfill can still operate until 2018. One solution that can be given in operation for the loop cycle or closed cycle concepts is landfill mining method, which is utilizing degraded waste into other designations so that the land can still be used to accommodate other waste. Sampling and analysis results show that the waste contained in 1st zone Piyungan landfill aged 15-20 years, with the highest composition is soil (59\%) dominate other types of waste. The soil obtained has the potential to be utilized as cover soil and compost, but for compost is necessary to further study the modification of the design of the zoning zone, so that the waste not too long is in the soil so that the nutrient content is still high.
\end{abstract}

\section{Introduction}

Access to national waste management services in 2013 reached $79.80 \%$ consisting of $87 \%$ of services in urban areas (resource management: $41 \%$ and final management: $46 \%$ ) and $72.60 \%$ in rural areas (source management: $69.2 \%$ and final management: $3.40 \%$ ). Until now, the available final processing area (landfill) in Indonesia has been $87 \mathrm{Ha}$, so that the target of service can be reached $100 \%$ by 2020 , it is projected to need a landfill area of $875 \mathrm{Ha}$ in all parts of Indonesia with the estimated cost of 13,120 trillion rupiah [1]. With a great value, surely this is not an easy job because the operation and maintenance are much difficult than the construction at the beginning.

The study conducted by InSwa [2] related to the operation of the existing landfill in Indonesia, shows the results of 10 landfills in the metropolitan city of Indonesia only $10 \%$ of which do the waste, closing with the soil once a week, while the other closes fortnightly $(40 \%)$, a month up to once a year $(50 \%)$. Similar conditions are also obtained from 14 landfills in major cities of Indonesia, 58\% of landfill closure from a period of a month to once a year, even $14 \%$ did not close at all during the operational period. The condition is due to many factors, including the unavailability of cover soil and high operational cost. Not only the closure of waste using the soil cover, the control of leachate and gas produced is still minimal management, so that newly constructed or rehabilitated landfill will be damaged again and can not work optimally and bring up various problems such as disease vector growth, air pollution, odor and smell, burning smoke, noise, social impact and pollution due to leachate.

Landfill management is a serious concern because of the increase of waste generation generated every time period. One of the causes is the increasing number of people in a region will affect the quantity of waste generated. Special Region of Yogyakarta Province one of 34 provinces owned by Indonesia, geographically located between $70^{\circ} 33^{\prime} \mathrm{LS}-8^{0} 12^{\prime} \mathrm{LS}$ and $110^{\circ} 00^{\prime} \mathrm{BT}$ $110^{0} 50^{\prime} \mathrm{BT}$. It has an area of $3,185.8 \mathrm{~km}^{2}$, consisting of 4 districts/cities, namely Sleman, Bantul, Gunungkidul, Kulonprogo, and Yogyakarta and is divided into 78 districts and 438 sub-districts/villages. The total population of Yogyakarta in 2015 reached 3,691,196 people, with the population still dominated in Sleman Regency by $31.78 \%$, Bantul Regency $26.58 \%$ and the rest spread evenly in three other areas. The highest population density is owned by the city of Yogyakarta, which reached 12,699 people $/ \mathrm{km}^{2}$ [3].

Based on National Standard of Indonesia (SNI) 193983-1995 of waste generation specification in Indonesia with potential waste generation reaching $3.25 \mathrm{~L} /$ person/day or equivalent to $0.8 \mathrm{Kg} /$ person/day,

\footnotetext{
"Corresponding author: hijrah@uii.ac.id
} 
this province has a potential waste production of $11,996 \mathrm{~m}^{3} /$ day or 2,953 tons/day [4]. Not all waste generated will end up in a landfill, some of which end up in unsustainable ways. Yogyakarta City has $85 \%$ waste level service, followed by Sleman Regency $30.71 \%$, Gunungkidul 17\%, Bantul $7.49 \%$ and Kulonprogo 7.2\% [4-6].

Yogyakarta City, Sleman and Bantul Regency have a final handling system for waste in the same location, namely Piyungan Regional Landfill located in Sitimulyo Village, Piyungan District, Bantul Regency, Yogyakarta. This landfill has an area of 12.5 ha and started its operation since 1995, the management has changed several times from the Cipta Karya of Public Works of Yogyakarta Province (1995-2000), continued management done by the Joint Secretariat (Sekber Kartamantul) (2000-2014) is currently managed under the Sanitation and Urban Water Supply Infrastructure Management Center (Balai PISAMP), Public Works Department and Housing of Special Province of Yogyakarta [4].

Piyungan landfill has a storage capacity of 2.7 million $\mathrm{m}^{3}$ of waste divided into 3 work zones. In planning the life of the TPA 15-20 years, should be in 2015, Piyungan landfill has expired. However, until 2017 it is still operated by optimizing 1 st zone which had previously been closed/full. However, the operation is expected to last only 1-2 years, so that in 2018 the Government of the Special Province of Yogyakarta must have a development plan for the landfill as a place to accommodate the waste that continues to be produced [7]. The reality in the field to find a new landfill location is very difficult, in addition to limited land, there is also a potential for high social conflicts in the community.

One of the methods that can be used in order to realize a sustainable landfill is a concept of "closed cycle" or "loop cycle" in landfill operations. The most feasible way to apply is landfill mining, an effort to recover beneficial ingredients from waste dumps in the landfill [8-11]. [12] Argue that the landfill mining method was first introduced in Tel Aviv, Israel in 1953 as a way of getting fertilizer for agricultural activities. Continued in India in 1989 as a pilot project of utilization of degraded organic matter as compost [8]. The Environmental Protection Agency (EPA) reported in 1993 that the first landfill mining activity was carried out with complete processing carried out at Collier Country Florida in 1986 [13]. This method continued to grow in the 1990 s, as evidenced by more articles writing about this theme, some 39 papers, derived from landfill mining studies in the US (50\%), Europe (30\%) and Asia (20\%) [11]. So the landfill mining method is one of the promising strategies to solve the problem of increasing the quantity of waste in a city, the limited land of the landfill, and minimizing the large funding for operational and postoperational activities of a landfill [14-15].

\section{Research Methodology}

In the landfill mining method, data on the composition of degraded waste according to the depth of the landfill is desirable. Sampling was conducted at 4 (four) points in 1st zone area of Piyungan Landfill, Bantul. Samples were taken by drilling using drill rig spindle type drill rig through spindle stroke with $7 \mathrm{~cm}$ diameter drilled per one meter up to 13 meters. The sample was analyzed for the composition, in order to identify the type of waste at each depth. Further testing of nutrients and heavy metals contents in the soil from various variations of landfill drilling depth was performed. Later, the results were compared with SNI 19-70302004 for compost specification from domestic organic waste and Regulation of Minister of Agriculture 70/2011 for organic fertilizer, biological fertilizer, and soil enhancers.

\section{Results and Discussion}

The unavailability of data related to the age of waste contained in each depth of waste pile, it takes a simple approach so that the waste can be known age. Using some data as follows: (1) the waste data goes to the landfill annually, (2) the total area of 1 st zone reaches $4 \mathrm{Ha}$ (since 1st zone is used as the sampling site); (3) the current waste density is estimated to reach $800 \mathrm{~kg} / \mathrm{m}^{3}$, (4) degradation factor occurring by $30 \%$, and (5) covering land used 3\% (for sanitary landfill have $15-20 \%$ cover soil ratio, 3\% figure is predicted because management of Piyungan landfill at 19952000 still not in accordance with applicable procedures). With that data, it is estimated that the depth of landfill in accordance with the operational time period (Table 1).

Table 1. Simple modeling of depth of waste dump in 1st Zone Piyungan landfill

\begin{tabular}{|c|c|c|c|c|}
\hline Year & $\begin{array}{c}\text { Total } \\
(\text { ton/ } \\
\text { year })\end{array}$ & $\begin{array}{c}\text { Total } \\
\left(\mathrm{m}^{3} /\right. \\
\text { year })\end{array}$ & $\begin{array}{c}\text { Degra- } \\
\text { dation } \\
(30 \%)\end{array}$ & $\begin{array}{c}\text { Cover } \\
\text { Soil } \\
(3 \%)\end{array}$ \\
\hline 1995 & 87.500 & 109.375 & 32.813 & 3.281 \\
\hline 1996 & 90.200 & 112.750 & 33.825 & 3.383 \\
\hline 1997 & 93.000 & 116.250 & 34.875 & 3.488 \\
\hline 1998 & 95.900 & 119.875 & 35.963 & 3.596 \\
\hline 1999 & 98.800 & 123.500 & 37.050 & 3.705 \\
\hline 2000 & 102.000 & 127.500 & 38.250 & 3.825 \\
\hline Total & $\begin{array}{c}\text { Total } \\
\left(\mathrm{m}^{3} /\right.\end{array}$ & $\begin{array}{c}\text { Total } \\
\text { (3) }\end{array}$ & $\begin{array}{c}\text { Height } \\
(\mathrm{m} /\end{array}$ & $\begin{array}{c}\text { Depth } \\
\text { Total } \\
(\mathrm{m})\end{array}$ \\
\hline Waste & year $)$ & $(2,4)$ \\
\hline 79.844 & 6.654 & 222 & 2,0 & 12,9 \\
\hline 82.308 & 6.859 & 229 & 2,1 & 10,9 \\
\hline 84.863 & 7.072 & 236 & 2,1 & 8,9 \\
\hline 87.509 & 7.292 & 243 & 2,2 & 6,8 \\
\hline 90.155 & 7.513 & 250 & 2,3 & 4,6 \\
\hline 93.075 & 7.756 & 259 & 2,3 & 2,3 \\
\hline
\end{tabular}

Source : [15] 
The result of simple modeling in Table 1 shows that waste from 15-16 years ago (1999-2000) is 4 meters deep from the surface of the soil, the depth of 4-8 meters is waste with predicted age of 17-18 years (1997- 1998), while the depth $>8 \mathrm{~m}$ to 13 meters is waste with predicted age $\pm 19-20$ years (1995-1996). Next per meter depth has separated the composition of the waste manually (maximizing the vision). Brief look samples comprise the majority of soil blackened, made possible because of the influence a long time in the soil litter. But after being parsed one by one, the more visible the difference between plastic, glass, cloth, metal, wood, bone, hair, paper and rubber.

In accordance with the understanding, the composition of waste is a representation of each component contained in waste and its distribution. The composition of waste is expressed in percent by weight of each component by the following equation:

$$
\% \text { weight }=\frac{\text { Weight of waste per composition }(\mathrm{kg})}{\text { Total weight of waste }} \times 100 \%
$$

Table 2. Composition of waste in each sampling depth

\begin{tabular}{|c|c|c|c|c|c|}
\hline \multirow[b]{2}{*}{$\begin{array}{l}\text { Depth } \\
\text { (m) }\end{array}$} & \multicolumn{5}{|c|}{ Weight Percentage (\%) } \\
\hline & Soil & $\begin{array}{c}\text { Plas- } \\
\text { tic }\end{array}$ & Glass & $\begin{array}{l}\text { Tex- } \\
\text { tile }\end{array}$ & $\begin{array}{c}\text { Me- } \\
\text { tal }\end{array}$ \\
\hline 1 & 44,27 & 34,16 & 1,37 & 12,48 & 1,24 \\
\hline 2 & 56,86 & 31,02 & 0,85 & 1,83 & 0,93 \\
\hline 3 & 70,87 & 22,07 & 0,21 & 1,51 & 0,08 \\
\hline 4 & 69,57 & 24,39 & 0,51 & 0,15 & 0,02 \\
\hline 5 & 67,97 & 26,19 & 0,61 & 0,66 & 0,38 \\
\hline 6 & 70,87 & 22,71 & 1,40 & 1,06 & 0,08 \\
\hline 7 & 57,44 & 30,28 & 1,11 & 2,22 & 0,87 \\
\hline 8 & 67,51 & 25,17 & 0,65 & 0,62 & 0,24 \\
\hline 9 & 49,56 & 32,91 & 0,79 & 1,94 & 3,51 \\
\hline 10 & 54,29 & 37,69 & 0,84 & 1,47 & 0,62 \\
\hline 11 & 48,51 & 43,47 & 0,48 & 3,80 & 0,12 \\
\hline 12 & 49,81 & 35,81 & 1,56 & 11,89 & 0,00 \\
\hline 13 & 59,52 & 32,47 & 0,75 & 2,22 & 0,60 \\
\hline Average & 59,00 & 30,64 & 0,86 & 3,22 & 0,67 \\
\hline \multirow{2}{*}{$\begin{array}{c}\text { Depth } \\
\text { (m) }\end{array}$} & \multicolumn{5}{|c|}{ Weight Percentage (\%) } \\
\hline & Wood & $\begin{array}{c}\text { Orga- } \\
\text { nic }\end{array}$ & Paper & & ober \\
\hline 1 & 6,40 & 0,00 & 0,00 & & 0,08 \\
\hline 2 & 5,03 & 2,40 & 0,67 & & 0,41 \\
\hline 3 & 2,41 & 2,59 & $0,1 \mathrm{C}$ & & 0,06 \\
\hline 4 & 4,36 & 0,00 & $0,4 c$ & & 0,54 \\
\hline 5 & 4,15 & 0,00 & 0,00 & & 0,04 \\
\hline 6 & 3,87 & 7,20 & 0,00 & & 0,01 \\
\hline 7 & 4,83 & 3,02 & 0,08 & & 0,09 \\
\hline 8 & 5,76 & 0,00 & $0,0($ & & 0,06 \\
\hline 9 & 10,28 & 0,02 & 0,00 & & 0,99 \\
\hline 10 & 4,39 & 0,26 & $0,0 \mathrm{C}$ & & 0,44 \\
\hline 11 & 3,26 & 0,00 & 0,00 & & 0,35 \\
\hline 12 & 0,69 & 0,21 & 0,00 & & 0,03 \\
\hline 13 & 4,00 & 0,00 & 0,00 & & 0,43 \\
\hline Average & 4,57 & 1,21 & 0,1 & & 0,27 \\
\hline
\end{tabular}

The waste composition per depth is shown in Table 2 , the soil dominates the results compared to other waste compositions, averaging $59 \%$; followed by plastic 30.64\%; wood 4.57\%; 3.22\% fabric; And the rest are glass, metal, organic bones and hair, and paper.

High soil components are derived from the degradation of organic waste, based on data of waste composition entering the Piyungan landfill dominated by organic waste, in the form of food, garden and garden waste $(64,41-68,52 \%)$, plastic, glass and metal (0.56-11.19\%), fabrics (3.49\%), wood (3.24-6.11\%) and paper (2.08-10.24\%) [7, 16]. With the composition of organic waste high so it is possible that the resulting soil is also high, besides the soil is derived from the soil cover used in the landfill operation [17].

Potential of soil is $59 \%$ from each sampling point, with a storage capacity of 2.7 million $\mathrm{m}^{3}$, the soil that can be obtained from the degradation of waste amounts to 1.5 million $\mathrm{m}^{3}$. Or if taken into account in more detail than the 4 sampling points based on the height of the soil $(6.28 \mathrm{~m})$, the soil volume of $175,950.47 \mathrm{~m}^{3}$ [17] is obtained. Of course, both approaches in determining the volume of soil produce large quantities, the soil is potentially useful for use as compost and as a cover for landfill applications under both controlled and sanitary landfill categories. Compost from the degradation of organic waste is very good for the plant, but because the composition of waste into the landfill is very mixed, it is necessary to test the quality of compost and contaminant content in it. Similarly, soil cover becomes an important issue, because so far the cost of soil cover becomes an obstacle from the operation of a landfill.

Research from [7] showed the results of testing on organic material owned by waste degradation land in Piyungan landfill has very low content. Only two samples have the appropriate organic material required by SNI 19-7030-2004, ie at sampling point 1 depth 4 $\mathrm{m}$ and sampling point 4 depth $8 \mathrm{~m}$. In contrast to the $\mathrm{C} / \mathrm{N}$ ratio, most of it fulfill the SNI requirement, which has at least a ratio of 10 , while only 3 samples whose $\mathrm{C} / \mathrm{N}$ ratio meet the requirements of Regulation of the Minister of Agriculture 70/2012. In general, the C/N ratio shows relatively low results compared to the requirements of organic compost.

The sample age will affect the quality of the nutrients it contains, with the sample age of 15-20 years, the organic material possessed by the waste in the form of carbon values has been depleted, causing the nutrients contained to be very low. If this soil will be utilized as organic fertilizer/compost it is necessary preliminary processing in order to increase the nutrients before applied to the plant. If the landfill will use the landfill mining concept, the operating zone's lifetime should be reduced so that the nutrient content of the degraded waste becomes higher.

While for metal parameters in soil analyzed include $\mathrm{Zn}, \mathrm{Cr}, \mathrm{Cu}, \mathrm{Cd}, \mathrm{Ni}, \mathrm{Pb}, \mathrm{Hg}, \mathrm{Mn}$ and Fe. All metals parameters meet the requirements as organic compost, except Lead $(\mathrm{Pb})$ which still exceeds the quality standard. The mixing of domestic urban waste with hazardous waste from domestic activities causes waste to potentially contain heavy metals, especially high $\mathrm{Pb}$ [7]. 


\section{Conclusion}

Based on sampling activities in order to plan a sustainable landfill, among the utilization of degraded waste that can be done as a compost and soil cover. Here are some points that can be concluded from this research:

a. The composition of degraded waste with aged 1520 years of age is dominated by soil $(59 \%)$. It is estimated that 1 st zone of Piyungan Landfill can produce 175,000 until 1.5 million $\mathrm{m}^{3}$ of soil.

b. The land obtained can be used as soil cover for landfill operations in other zones, while the mined zone can be reused as a new zone and ready to accommodate other waste.

c. The potential of soil for compost still needs to be studied because of the very low nutrients and the potential of heavy metals contained therein. Low nutrient content can be anticipated by improvements in the design of the zone of exposure especially regarding aspects of life. Age of waste will affect the nutrients contained

\section{References}

1. Direktorat Jenderal Cipta Karya, Buku pedoman penyelenggaraan pembangunan bidang Cipta Karya, Volume 4 : Pengembangan pengelolaan persampahan, Kementerian Pekerjaan Umum dan Perumahan Rakyat, Indonesia (2015)

2. Inswa, Indonesia Solid Waste Newsletter : Untuk Indonesia yang lebih bersih, Edisi 2 Maret 2013, Jakarta (2013)

3. BPS Yogyakarta, Data Jumlah Penduduk Propinsi Daerah Istimewa Yogyakarta (2016)

4. H.P. Putra, E. Damanhuri, Performance and Operational of Landfill Piyungan as The Regional Landfill in Yogyakarta Special Region, Indonesia. In Proceding of The 9th Asia-Pacific Landfill Symposium. University of Hongkong. Hongkong (2016)

5. BLH DIY, Rencana Aksi Sampah Daerah DIY. Yogyakarta, Indonesia (2014)

6. S.A. Mulasari, A.H. Husodo, N. Muhadjir, Kebijakan pemerintah dalam pengelolaan sampah domestik. Kesmas, Jurnal Kesehatan Masyarakat Nasional, Vol 8 No 8, 404-410 (2014)

7. H.P. Putra, A. Marzuko, K. Sari, T. Septhiani, F. Rahmadani, Identification of compost potential on degraded solid waste in Piyungan landfill, Bantul, Yogyakarta as a step of landfill mining management optimization by using landfill mining methode, In Proceding of 4th International Conference on Sustainable Built Environment, Faculty of Civil Engineering and Planning, Universitas Islam Indonesia, Yogyakarta (2016)

8. C. Barlow, W. Iqbal, S. Ashton, Landfill mining, Publication of University of Cambridge, Institute for Manufacturing, Departement of Engineering, download from https://www.srcf.ucam.org/awtbi/ documents/Landfillmining.pdf. (2002).

9. Direktorat PPLP. Materi Bidang Sampah : Diseminasi dan Sosialisasi Keteknikan Bidang Penyehatan Lingkungan Permukiman, Direktorat Jenderal Cipta Karya, Kementerian Pekerjaan Umum, Indonesia (2012)

10. R. Schreiber, C. Russell, D. Abeln, Regulatory requiremen, Paper 5 in Procedings of Global Landfill associated with landfill mining in the United States, Paper 4 in Procedings of Global Landfill Mining Conference and Exhibition, PRo Publication International Ltd, UK (2010)

11. J. Krook, N. Svensson, M. Eklund, Landfill Mining: A Critical Review of Two Decades of Research. Waste Management Journal 32, pp.513520 (2012)

12. G.M. Savage, C.G. Golueke, E.L. von Stein, Landfill mining: past and present, Biocycle Journal 34, 58-61 (1993)

13. R. Goeschl, System, technology and experience of $17 \mathrm{Mt}$ of landfill mining projects, Paper 5 in Procedings of Global Landfill Mining Conference and Exhibition, PRo Publication International Ltd, UK (2010)

14. W. Dickinson, Landfill mining comes of age. Solid Waste Technologies, 9, 42-47 (1995)

15. H.P. Putra, D. Afrillah, A. Marzuko, Analisis karakteristik dan potensi pemanfaatan sampah plastik dari hasil penambangan sampah di Tempat Pemrosesan Akhir (TPA) (studi kasus TPA Piyungan, Bantul, Yogyakarta), in Proceding National Conference Menuju Masyarakat Madani dan Lestari, DPPM Universitas Islam Indonesia, Yogyakarta (2015)

16. K.P. Adidarma, L.M. Al Rosyid, H.P. Putra, and A.U. Farahdiba, Gas emissions inventory of methane (CH4) with First Order Decay (FOD) method in Piyungan Landfill, Bantul, DIY, In: Proceedings The 3rd International Conference on Sustainable Built Environment (ICSBE), Faculty of Civil Engineering and Planning, Universitas Islam Indonesia, Yogyakarta, Indonesia (2014)

17. H.P. Putra, E. Damanhuri, A. Marzuko. Landfill Mining Prospect in Indonesia. In Proceeding of 3rd Symposium of the Asian Regional Branch of International Waste Working Group. Seoul National University. Seoul (2017) 